\title{
Granite fracture index to check suitability of granite outcrops for quarrying
}

\author{
Luís M.O. Sousa* \\ Department of Geology, Universidade de Trás-os-Montes e Alto Douro, Apartado 1013, 5001-801 Vila Real, Portugal
}

Received 28 December 2006; received in revised form 3 April 2007; accepted 12 April 2007

Available online 19 April 2007

\begin{abstract}
A correct knowledge of fracture patterns previous to quarrying is important for economical exploitation. This work comprises the general characterization of the discontinuities of 10 granite rock masses in NE Portugal. During the study some discontinuity characteristics such as orientation, persistence, aperture, trace length and spacing were evaluated. The differences in the characteristics of the selected granites were described, and the most important exploration factors were identified. In the granites studied, most of the joints are oriented from $\mathrm{N} 10^{\circ} \mathrm{E}$ to $\mathrm{N} 50^{\circ} \mathrm{E}$, which is compatible with the regional fracture pattern. Concerning joint termination, the XX type is common, while the RR type is rare; the persistence index ranges from $3.5 \%$ to $25.4 \%$. Closed joints are predominant in the granites studied $(>72.4 \%$ ), and openings of the others are about $1-2 \mathrm{~mm}$ as a result of superficial displacement of the granite blocks. The percentage of filled joints, usually by quartz and pegmatite, is different from one granite to another, but most are $<20 \%$. The average joint length ranges from $11.1 \mathrm{~m}$ in post-tectonics granites to $4.6 \mathrm{~m}$ in syntectonic granites. Joint spacing varies from 0.98 to $2.8 \mathrm{~m}$ with higher values in post-tectonic granites. Joint-space distributions of the granites studied are close to log-normal and exponential distributions. Volumetric joint count (Jv) ranges from 0.8 to 2.1 joints $/ \mathrm{m}^{3}$ and is used for categorizing the places of each granite. The relationships between $\mathrm{Jv}$ and other joint characteristics, such as length, spacing and number of joint sets, were investigated. A Granite Fracturing Index (GFI) is introduced, computed on the basis of volumetric joint count, number of joint sets and true joint spacing. The GFI classification of studied places allows us evaluate the suitability for profitable exploitation.
\end{abstract}

(C) 2007 Elsevier B.V. All rights reserved.

Keywords: Discontinuity; Rock mass; Fracturing; Dimension granite; Exploitation; Granite fracture index

\section{Introduction}

Previous to quarrying, several types of detailed work in the field and in the laboratory have to be applied, and one of the most important assessments is fracture evaluation. Large blocks are required by industrial processing and the natural fracture pattern of the rock mass directly controls its large blocks yield capability. The systematic

\footnotetext{
* Fax: +351259350480.

E-mail address: 1sousa@utad.pt.
}

study of fracture patterns is important for evaluating the possibility of exploiting appropriate sized and qualified rock blocks - i.e., the exploitation viability. Several authors studied and quantified, in several places and for distinct rocks, the raw material exploitable as commercial blocks (Toyos et al., 1994; Tomašic, 1994; Sonmez et al., 2004). The fractures must be studied in all scales, from microfractures to regional faults, including their physical characteristics (spacing, filling, etc.) (I.S.R.M., 1978; Wang et al., 2003). The orientation of the joint sets in rock mass controls the shape of rock blocks and is 
desirable two sub-vertical and perpendicular joint sets, because the natural blocks will be a cubic or parallelepiped shape. Randomly oriented joints, therefore, will affect the recovery of suitable blocks. The joint-trace length is one of the most important attributes for evaluating the geomechanical quality of rock mass, and for that reason, was studied by many authors (Cruden, 1977; I.S.R.M., 1978; Pahl, 1981; Xing and Guohua, 1990; Jimenez-Rodriguez and Sitar, 2006b; Pine et al., 2006). The joints tend to be isotropic, with the length along direction similar to the length along the dip direction (Robertson, 1970; Song, 2006). The type of joint termination permits classifying the persistence of the several joint sets present in the rock mass (I.S.R.M., 1978). Assuming discontinuities as circular (Priest, 1993), the joints of short length and terminating in rock outcrop or against other joints do not extend deeply inside the rock mass. In massive rocks, such as the granites studied, the influence of these joints in an eventual exploitation will not be significant. Field observations in granite quarries confirm the diminution of jointing at depth. Aperture and filling are not very important in the study of rock mass for quarry installation purposes. Joints with high apertures and/or filling denote their continuity, and these observations are important in joint-set identification. Roughness characteristics are related to mechanical properties (Jiang et al., 2006) but usually are not relevant in granite quarrying. The distance between joints with similar orientation (spacing) its one important factor in exploration and exploitation of natural stone, as the joint spacing controls the size of individual blocks in the rock mass. Simulating the division of a specified volume of rock by several joint sets is possible, using algorithms (Maerz and Germain, 1996; Wang et al., 2003).

Granites are common in the north of Portugal, and some of them have been exploited as dimension stone. Geological approach is not usually utilized to choose new exploration areas and the consequences are not commercial explorations and environmental problems. The main purpose of this study is evaluating the suitability to provide commercial blocks of 10 granites from NE Portugal by studying the main fracture characteristics. We point out the similarities and the differences in discontinuity characteristics, such as orientation, length, joint termination, aperture, filling and spacing, and recognize the factors that control their differences or similarities. A fracturation index based up on joint characteristics is proposed to make easier to compare several outcrops.

\section{General properties of the granites studied}

The granites studied locate in NE Portugal (Fig. 1) and are different types such as: post-tectonic and syntectonic granites of the third phase of the Hercynian orogeny. These granites are medium to coarse grained. Some of them have a porphyritic texture (Sousa et al., 2005), and others have been exploited for dimension stone (Sousa, 2000).

\section{Methodology}

Based upon observations conducted on the outcrops and aerial photographic interpretation (15:000 scale), we selected the more desirable sites for possible quarry installation, taking into consideration the degree of jointing, weathering, accessibility and available area. These selected sites must be sufficiently distant from regional faulting, where joint density is lower (Tansi et al., 2000; Greco and Sorriso-Valvo, 2005). These data, obtained by photo interpretation, are also important for evaluating the jointing in relation to regional fracture patterns. Data from the Pedras Salgadas and Mourão granites were acquired directly in quarries.

In all visible sub-vertical joints of previously selected places, orientation, length, aperture, filling, termination and spacing were evaluated (Fig. 2). Sub-horizontal jointing was not taken into account, because their influence on granite exploitation is not prejudicial. In granitic rocks the sub-horizontal joints are consequence of erosion and stress release, and their density decreases at depth. According to the data obtained in granite quarries in NE Portugal (Sousa, 2000; Morais, 2003) we understand that joints are essentially of the sub-vertical type. Data from quarries (Pedras Salgadas and Mourão granites) also include dip data. At all places a rock-mass area with at least $50 \times 50 \mathrm{~m}^{2}$ was selected (some reach $100 \times 50 \mathrm{~m}^{2}$ ) where the fracture characteristics were systematically acquired. We use this methodology instead of the scan-line method (or another method) because the density and joint orientation are not random; then we acquired data from all visible fractures. In the outcrops of 8 granites we selected 80 places and also 14 quarries in the Pedras Salgadas and Mourão granites, and collected data from 12,067 joints. In quarries, we also obtained the dips, but it was impossible to know the termination types.

The achievement of these data was influenced by the cleanliness of rock surfaces, which is dependent on the local humidity, the season of the year and the topography. The presence of lichens, which are common, and the presence of coating obscured the joint visibility, especially for determining length and termination. Special attention should be devoted to this process so as not to reach erroneous conclusions; experience in rock-outcrop observation and data acquiring is fundamental at this stage. 


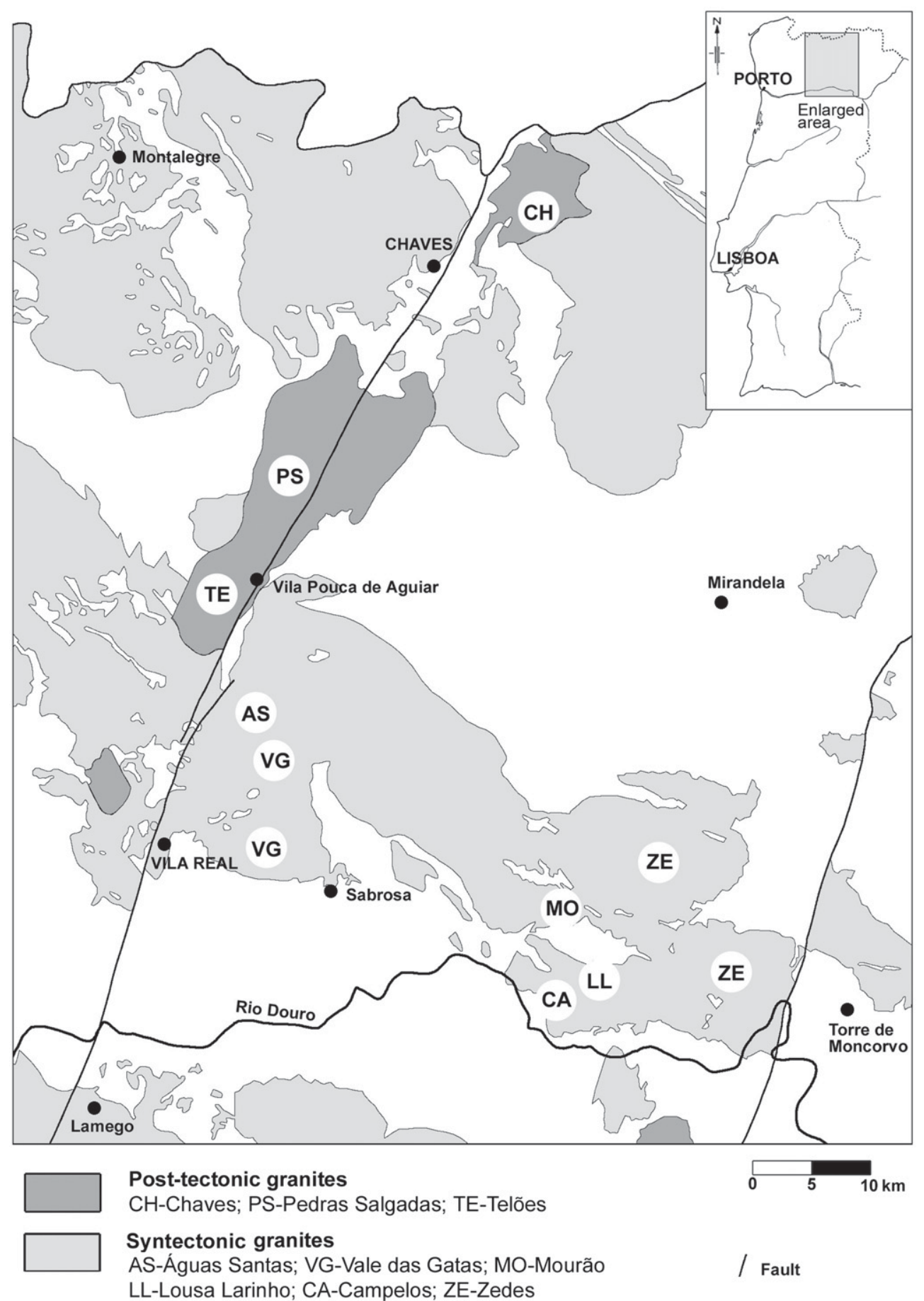

Metamorphic rocks

Fig. 1. Locations of the studied granites (after Sousa et al., 2005).

Joint orientation was the most difficult parameter to obtain because of both the conditions referred to and the lack of a third direction of observation (observations on rock surfaces do not allow viewing the dip directions). For these reasons, we only get the joint direction by observing their trace on rock surfaces. Based on joint 


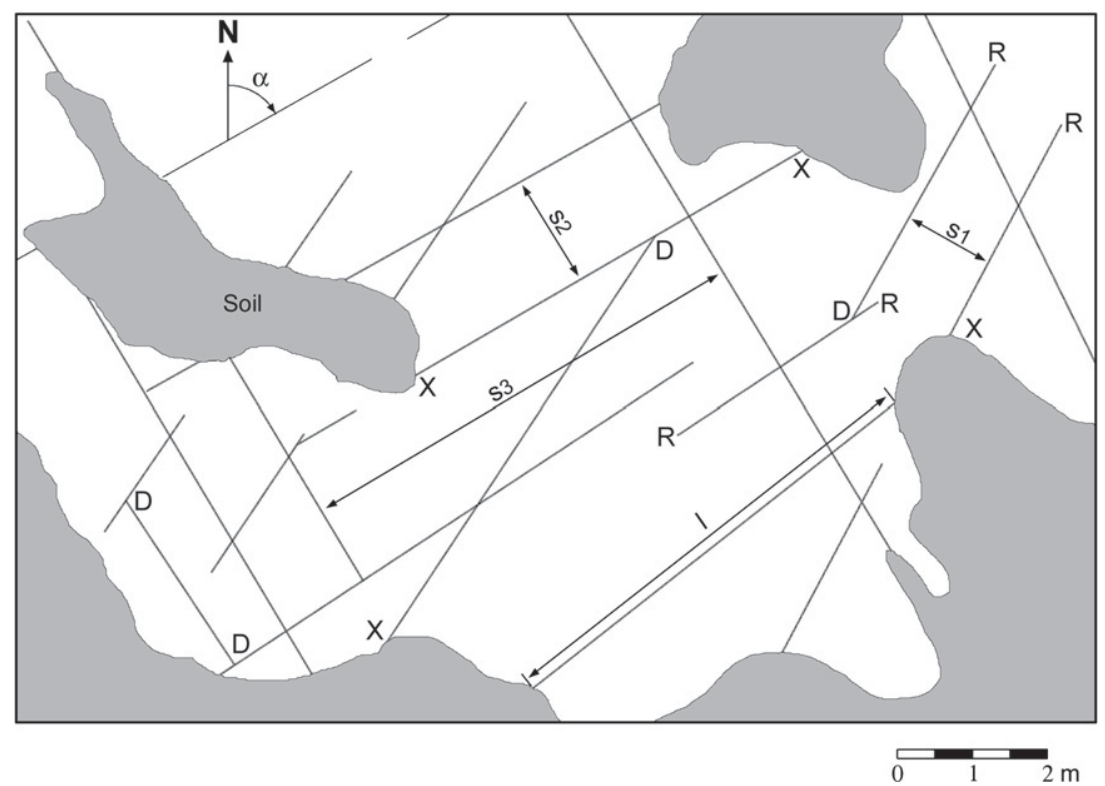

Fig. 2. Scheme of a hypothetical outcrop. In selected places, information for each joint was obtained for the direction $(\alpha)$, length $(l)$, and termination type (DD, DR, DX, RR, RX and XX). The spacing of joint sets was obtained in a direction perpendicular to discontinuities (figure represented only one spacing for each joint set: s1, s2 and s3).

directions, we can identify the principal joint sets. According to several authors, the frequency is significant when superior at $E+2 * S$ (Davis, 1986) ( $E$ is the weighted frequency and $S$ is the standard deviation). Joint-set identification by this method is simple and avoids more complex analysis like the one proposed by Jimenez-Rodrigues and Sitar (2006a). For the granites studied, however, joint-set identification was simple because the joints are grouped in distinguishable sets.

Persistency of joints is characterized by their termination in accordance with the procedure suggested by I.S.R.M. (1978). According to this procedure, rock $(R)$, where the termination occurs in rock; discontinuity $(D)$, where the joint ends in another joint; and uncertain $(X)$, where the joint does not end in a visible rock surface. On the basis of the number of terminations of each type, the termination or persistency index was achieved (I.S.R.M., 1978), notated below as Jp.

True joint spacing was measured for each joint set, like those illustrated in Fig. 2, and their respective average values were computed. For discontinuity characterization at each place where joint sets were identified, several parameters such as volumetric joint count (Jv), number of joint sets $(\mathrm{Jn})$, overall average joint spacing $(\mathrm{Js})$, average joint length $(\mathrm{Jl})$ and joint persistence $(\mathrm{Jp})$ were calculated.

A volumetric joint count (Jv) was proposed by I.S.R.M. (1978) and is useful for assessing block sizes. Jv was computed in accordance with the suggestions of Palmström (1982) (Eq. (1)), using all true spacing data

Table 1

Joint azimuth summary in granites under study (abbreviations can be found in Fig. 1)

\begin{tabular}{|c|c|c|c|c|c|c|c|c|c|c|c|}
\hline & & \multicolumn{10}{|c|}{ GRANITES } \\
\hline & & $\begin{array}{l}\text { CH } \\
n=372\end{array}$ & $\begin{array}{l}\text { PS } \\
n=1088\end{array}$ & $\begin{array}{l}\mathrm{TE} \\
n=1148\end{array}$ & $\begin{array}{l}\text { AS } \\
n=5762\end{array}$ & $\begin{array}{l}\mathrm{VG} \\
n=1121\end{array}$ & $\begin{array}{l}\mathrm{MO} \\
n=366\end{array}$ & $\begin{array}{l}\mathrm{LL} \\
n=584\end{array}$ & $\begin{array}{l}\text { CA } \\
n=470\end{array}$ & $\begin{array}{l}\mathrm{ZE} \\
n=897\end{array}$ & $\begin{array}{l}\mathrm{AR} \\
n=259\end{array}$ \\
\hline Azimuth & $\begin{array}{l}E+2 * \mathrm{~S}(\%) \\
\text { s1 mode }(\%) \\
\text { azimuth }\left({ }^{\circ}\right) \\
\text { s2 mode }(\%) \\
\text { azimuth }\left({ }^{\circ}\right) \\
\text { s3 mode }(\%) \\
\text { azimuth }\left({ }^{\circ}\right)\end{array}$ & $\begin{array}{l}9.1 \\
28.0 \\
90-100\end{array}$ & $\begin{array}{l}7.6 \\
10.4 \\
70-80 \\
9.6 \\
20-30\end{array}$ & $\begin{array}{l}7.5 \\
14.9 \\
10-20 \\
14.9 \\
80-90\end{array}$ & $\begin{array}{l}6.4 \\
9.2 \\
40-50 \\
8.7 \\
90-100 \\
8.1 \\
130-140\end{array}$ & $\begin{array}{l}7.6 \\
11.8 \\
20-30\end{array}$ & $\begin{array}{l}10.0 \\
25.6 \\
40-50 \\
12.0 \\
140-150\end{array}$ & $\begin{array}{l}8.4 \\
12.2 \\
30-40\end{array}$ & $\begin{array}{l}8.7 \\
14.3 \\
20-30\end{array}$ & $\begin{array}{l}7.8 \\
21.5 \\
20-30\end{array}$ & $\begin{array}{l}9.8 \\
16.2 \\
120-130 \\
15.1 \\
60-70\end{array}$ \\
\hline
\end{tabular}

$n-$ number of joints; $E+2 * S-$ threshold of significant frequency; s1, s2, s3 - joint sets. 


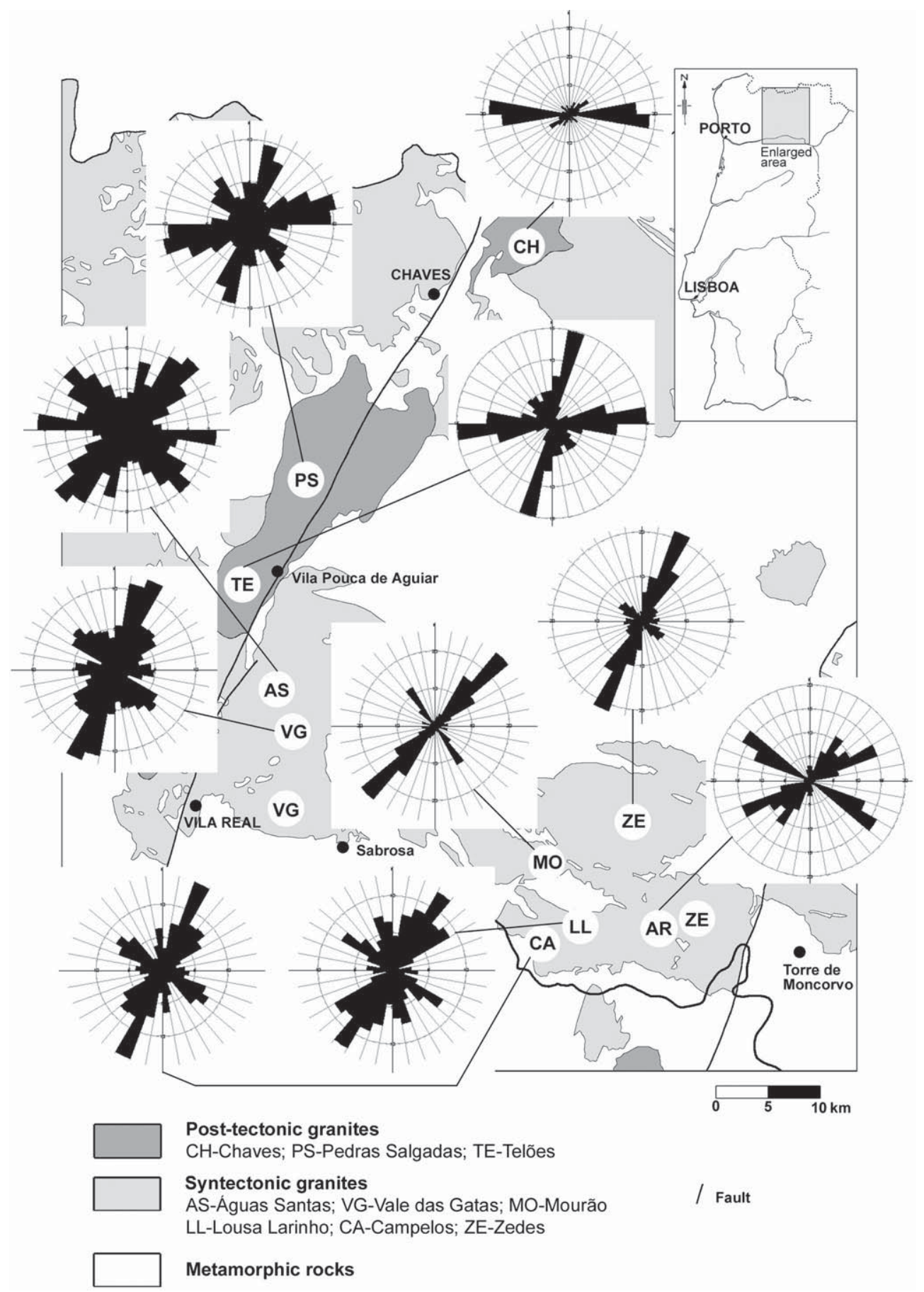

Fig. 3. Rose diagram of joints encountered in granites.

obtained from the rock-surface method instead of from the scan-line method:

$$
\mathrm{JV}=\frac{1}{S_{1}}+\frac{1}{S_{2}}+\frac{1}{S_{3}}+\ldots
$$

where $S_{1}, S_{2}, S_{3}$ are the average joint spacing, obtained by measuring in a perpendicular direction to each discontinuity set $(1,2$, and 3$)$. Subhorizontal joints, where widely spaced (usually the case), are not negative for quarry exploitation, and only sub-vertical joints were 
Table 2

Joint termination type and respective termination index (Jp) (abbreviations can be found in Fig. $3 ; n$ - number of joints)

\begin{tabular}{|c|c|c|c|c|c|c|c|c|c|c|}
\hline \multirow[b]{2}{*}{ Termination } & \multicolumn{10}{|c|}{ GRANITES } \\
\hline & $\begin{array}{l}\mathrm{CH} \\
n=372\end{array}$ & $\begin{array}{l}\mathrm{PS}^{\mathrm{a}} \\
n=1088\end{array}$ & $\begin{array}{l}\mathrm{TE} \\
n=1148\end{array}$ & $\begin{array}{l}\text { AS } \\
n=5762\end{array}$ & $\begin{array}{l}\mathrm{VG} \\
n=1121\end{array}$ & $\begin{array}{l}\mathrm{MO}^{\mathrm{a}} \\
n=366\end{array}$ & $\begin{array}{l}\mathrm{LL} \\
n=584\end{array}$ & $\begin{array}{l}\mathrm{CA} \\
n=470\end{array}$ & $\begin{array}{l}\mathrm{ZE} \\
n=897\end{array}$ & $\begin{array}{l}\text { AR } \\
n=259\end{array}$ \\
\hline DD (\%) & 3.0 & & 12.2 & 16.7 & 17.6 & & 1.9 & 9.2 & 3.9 & 1.9 \\
\hline DR (\%) & 7.0 & & 15.2 & 12.0 & 17.7 & & 1.9 & 3.2 & 3.6 & 3.1 \\
\hline DX (\%) & 18.0 & & 23.5 & 22.5 & 17.5 & & 15.8 & 16.9 & 13.0 & 20.1 \\
\hline RR (\%) & 6.2 & & 9.1 & 6.7 & 8.5 & & 0.2 & 1.2 & 0.7 & 2.7 \\
\hline RX (\%) & 15.6 & & 17.3 & 10.6 & 10.0 & & 4.5 & 5.4 & 7.3 & 11.6 \\
\hline XX (\%) & 50.2 & & 22.7 & 31.5 & 28.7 & & 75.7 & 64.1 & 71.5 & 60.6 \\
\hline Jp (\%) & 17.47 & & 25.39 & 17.98 & 22.39 & & 3.34 & 5.44 & 6.08 & 10.04 \\
\hline
\end{tabular}

${ }^{a}$ Observation in quarries; there is no termination data.

used in the determination of Jv. Jn is defined as the number of joint sets in Jv computation. The average joint spacing (Js) is based on the overall spacing data and also includes the data of random joints - i.e., joints not included in a particular set (Eq. (2)):

$\mathrm{JS}=\frac{\sum s_{i}}{N_{s}}$

where $s_{i}$ is the true average spacing and $N_{S}$ is the number for data spacing. Average joint length is obtained from the trace lengths on the rock surface (Eq. (3)):

$\mathrm{J} 1=\frac{\sum l_{i}}{N_{1}}$

where $l_{i}$ is the joint-trace length, and $N_{1}$ the number for data length (usually equal to the number of joints). Joint persistence is defined as the percentage of termination in rock $(R)$ relative to the total of terminations $\left(\sum R+\sum D+\right.$ $\left.\sum X\right)$ (I.S.R.M., 1978) (Eq. (4)):

$\mathrm{Jp}=\frac{N_{R}}{2 N}$

where $N_{R}$ is the number of terminations on rock mass, and $N$ is the number of joints.

\section{Results and discussion}

Because of the large number of sites studied, a general-results analysis was carried out to compare the different granites. However, the number of sites studied and joints mapped vary from granite to granite, and any conclusions must consider this fact.

\subsection{Joint orientation}

In the granites studied, most joints fall within an orientation of $\mathrm{N} 10^{\circ} \mathrm{E}$ to $\mathrm{N} 50^{\circ} \mathrm{E}$ (Table 1 and Fig. 3). This pattern is compatible with regional fracturing, which was predominantly shaped by NNE-SSW structures of tectonic origin (Lourenço et al., 2002). Two most important regional faults of NE Portugal, such as the Vila Real Fault and the Vilariça Fault, are locate near of the granite masses investigated (see Fig. 1).

The association between local and regional fracturing is not always clear because a large number of secondary faults with distinct orientation, and the jointing reflects this fact (Gamond and Giraud, 1982). In some places joints are linked to these secondary faults and the major ones are not identified in rock mass jointing. In adjacent places under the tectonic influence of the same regional faults, it is possible to observe different patterns

Table 3

Joint aperture (abbreviations can be found in Fig. $3 ; n-$ number of joints)

\begin{tabular}{|c|c|c|c|c|c|c|c|c|c|c|}
\hline \multirow[b]{2}{*}{ Aperture } & \multicolumn{10}{|c|}{ GRANITES } \\
\hline & $\begin{array}{l}\mathrm{CH} \\
n=372\end{array}$ & $\begin{array}{l}\mathrm{PS}^{\mathrm{a}} \\
n=1088\end{array}$ & $\begin{array}{l}\text { TE } \\
n=1148\end{array}$ & $\begin{array}{l}\text { AS } \\
n=5762\end{array}$ & $\begin{array}{l}\mathrm{VG} \\
n=1121\end{array}$ & $\begin{array}{l}\mathrm{MO}^{\mathrm{a}} \\
n=366\end{array}$ & $\begin{array}{l}\mathrm{LL} \\
n=584\end{array}$ & $\begin{array}{l}\text { CA } \\
n=470\end{array}$ & $\begin{array}{l}\mathrm{ZE} \\
n=897\end{array}$ & $\begin{array}{l}\mathrm{AR} \\
n=259\end{array}$ \\
\hline Indeterminate $(\%)$ & 8.9 & & 13.3 & 12.0 & 4.1 & & 4.1 & 3.7 & 8.2 & 0.4 \\
\hline Open $(\%)$ & 2.4 & & 14.3 & 14.4 & 3.7 & & 0.0 & 0.6 & 1.6 & 0.0 \\
\hline Closed (\%) & 88.7 & & 72.4 & 73.6 & 92.2 & & 95.9 & 95.7 & 90.2 & 99.6 \\
\hline
\end{tabular}

\footnotetext{
a Observation in quarries; there is no termination data.
} 
Table 4

Average joint length (meters) in studied granites (abbreviations can be found in Fig. 3)

\begin{tabular}{|c|c|c|c|c|c|c|c|c|c|c|c|}
\hline \multirow[b]{2}{*}{ Joint attribute } & & \multicolumn{10}{|c|}{ GRANITES } \\
\hline & & $\mathrm{CH}$ & $\mathrm{PS}^{\mathrm{a}}$ & $\mathrm{TE}$ & AS & VG & $\mathrm{MO}^{\mathrm{a}}$ & LL & CA & $\mathrm{ZE}$ & AR \\
\hline \multirow[t]{6}{*}{ Termination } & DD & 7.30 & & 10.24 & 3.67 & 6.26 & & 2.76 & 5.66 & 6.91 & 2.66 \\
\hline & DR & 9.32 & & 8.80 & 3.60 & 5.32 & & 4.19 & 8.30 & 4.03 & 2.66 \\
\hline & DX & 9.25 & & 12.61 & 5.66 & 8.03 & & 4.78 & 7.19 & 6.63 & 3.66 \\
\hline & RR & 6.27 & & 6.85 & 3.11 & 4.01 & & 2.40 & 4.93 & 4.67 & 2.60 \\
\hline & $\mathrm{RX}$ & 9.56 & & 10.04 & 4.83 & 6.98 & & 4.39 & 6.31 & 7.88 & 3.88 \\
\hline & $\mathrm{XX}$ & 11.87 & & 14.18 & 6.47 & 8.70 & & 5.69 & 8.56 & 9.76 & 5.36 \\
\hline \multirow[t]{3}{*}{ Aperture } & Indeterminate & 13.59 & & 13.63 & 6.18 & 11.62 & & 11.25 & 17.88 & 14.73 & - \\
\hline & Open & 14.02 & & 13.07 & 6.12 & 7.58 & & - & 17.95 & 11.14 & - \\
\hline & Close & 9.96 & & 10.29 & 4.69 & 6.74 & & 5.15 & 7.44 & 8.29 & - \\
\hline \multirow[t]{2}{*}{ Filling } & Yes & 14.69 & & 12.18 & 7.88 & 10.12 & & 5.56 & 9.25 & 11.06 & 6.50 \\
\hline & No & 9.92 & & 11.11 & 4.81 & 6.08 & & 4.92 & 7.09 & 8.09 & 4.17 \\
\hline Total average & & 10.38 & & & 5.08 & 6.99 & & 5.40 & 7.89 & 8.64 & 4.64 \\
\hline
\end{tabular}

${ }^{\text {a }}$ Observation in quarries; there is no termination data.

of jointing. This situation is common and has been verified by several authors (Lisboa, 1998).

Primary granite joints are linked with magmatic processes and are directly related to their fluid structures (Balk, 1937; Marre, 1986; Pitcher, 1993). Transverse joints were formed previously and were filled frequently by residual magmatic liquids that were the source of aplitic and pegmatitic materials (Marre, 1986). The longitudinal jointing is parallel to the fluidity (Dutartre, 1982), and their identification allow us classify the joints.

Syntectonic regional granites of NE Portugal show a clear magmatic lineation with strikes of $\mathrm{N} 40^{\circ}-60^{\circ} \mathrm{W}$ (Matos, 1991; Sousa, 2000). Thus, in this region the granites should present two joint sets of primary origin: $\mathrm{N} 40^{\circ}-60^{\circ} \mathrm{W}$, parallel to the magmatic lineation, and $\mathrm{N} 30^{\circ}-50^{\circ} \mathrm{E}$, perpendicular to the magmatic lineation. The last set is not easily visible because of the presence of the NNE-SSW secondary tectonic fractures, which are superimposed on the magmatic fractures. When we analyze the data from each site, however, these relationships can be seen more clearly.

\subsection{Joint persistency}

In the granites, the $\mathrm{XX}$ type joint persistency is more common, and the RR type is in minority (Table 2). XX type joints are usual in Lousa-Larinho, Campelos, Zedes and Arejadouro granites and consequently the termination index is low. Joints are less persistent in the Chaves, Telões, Águas Santas and Vale das Gatas granites $\left(17.5 \%<T_{r}<25.4 \%\right)$ as inferred from the proportion of joints with termination on rock mass $(28.8 \%<R<$ $41.6 \%)$.

A large proportion of joints with termination on rock mass and of short length possibly indicates a decrease in the density of fractures at depth, and therefore better conditions for rock exploitation, because joints tend to be circular where they terminate in rock and straight where they terminate in other joints (I.S.R.M., 1978). However, joints that terminate in rock mass ( $\mathrm{R}$ type) can be adverse in rock exploitation because the natural subdivision of rock mass is not clear before quarry installation and even during the exploitation process. In Chaves, Telões, Águas Santas and Vale das Gatas granites $\mathrm{R}$ joint type is common and these granites are more suitable for quarrying.

\subsection{Aperture and joint-trace length}

Aperture is one of the discontinuity parameter evaluated difficultly in some investigated places because of the soil cover. Closed joints are predominant in

Table 5

Average and median spacing values of all data spacing (abbreviations can be found in Fig. $3 ; n$ - number of data)

\begin{tabular}{|c|c|c|c|c|c|c|c|c|c|c|c|}
\hline & & \multicolumn{10}{|c|}{ GRANITES } \\
\hline & & $\mathrm{CH}$ & PS & $\mathrm{TE}$ & AS & VG & MO & LL & $\mathrm{CA}$ & $\mathrm{ZE}$ & AR \\
\hline \multirow{3}{*}{ S } & $n$ & 169 & 367 & 587 & 2041 & 367 & 87 & 188 & 151 & 136 & 91 \\
\hline & Average & 1.56 & 1.50 & 2.88 & 1.25 & 1.50 & 1.42 & 1.43 & 1.16 & 2.49 & 0.98 \\
\hline & Median & 1.20 & 1.10 & 1.90 & 1.00 & 1.10 & 1.00 & 1.03 & 0.95 & 1.40 & 0.90 \\
\hline
\end{tabular}



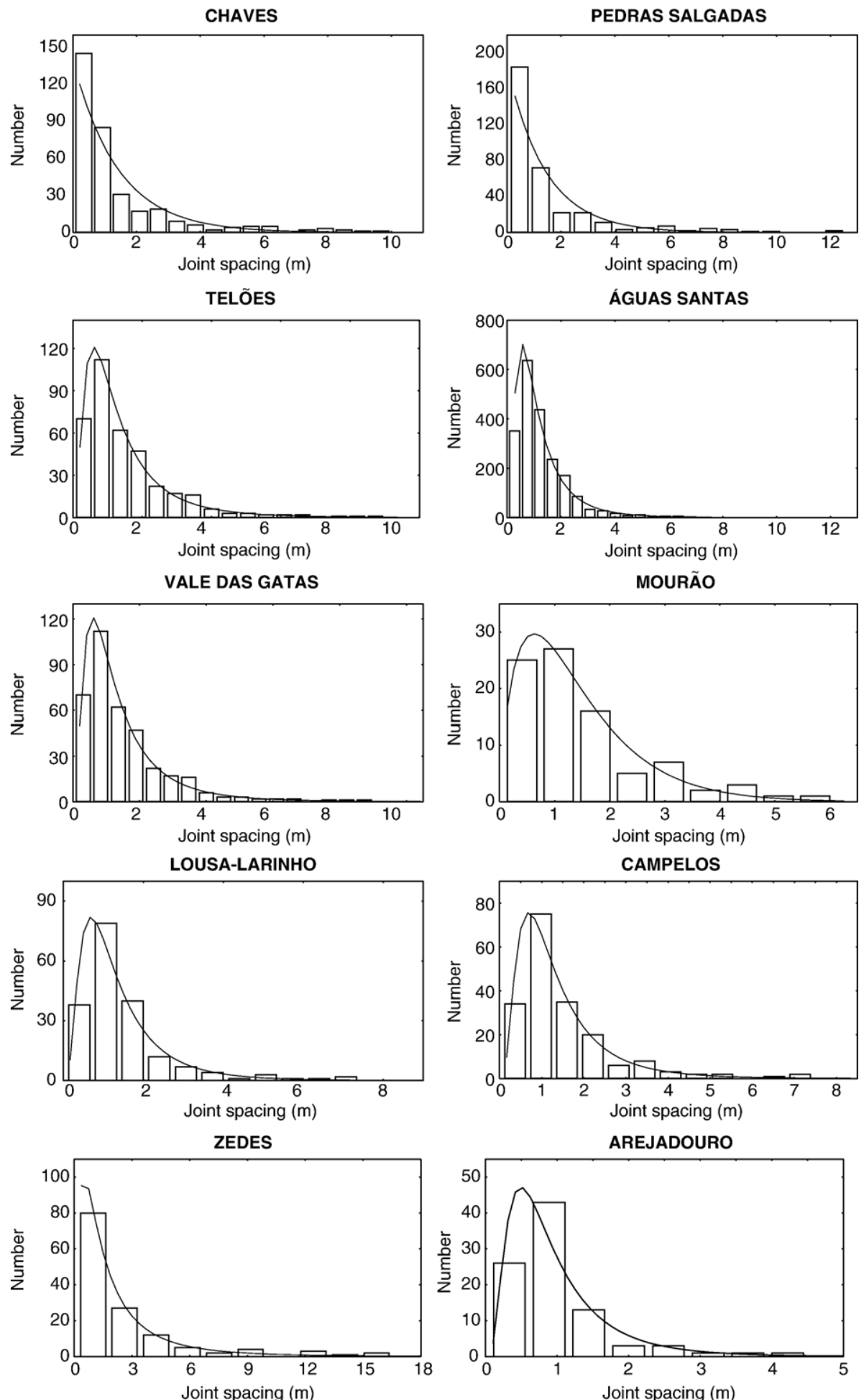

Fig. 4. Joint spacing distribution in studied granites (Chaves and Pedras Salgadas granites: exponential best-fit; others granites: log-normal best-fit). 
the granites studied $(>72.4 \%$ ) (Table 3$)$. Open joints in investigated granites, about $1-2 \mathrm{~mm}$ wide, have resulted from superficial displacement of the rock blocks. The proportion of filled joints with quartz and pegmatite of millimeter-size differ along investigated granites, but is usually $<20 \%$.

Chaves $(10.4 \mathrm{~m})$ and Telões $(11.1 \mathrm{~m})$ granites have high average values of joint length, differing from the other granites. Since these two granites are post-tectonic their outcrop areas are large and joints length reproduces this fact. Arejadouro (4.6 m), Águas Santas (5.1 m) and Lousa-Larinho $(5.4 \mathrm{~m})$ granites presents smaller joint length (Table 4).

The XX joints cross the visible rock outcrop and therefore exhibit the largest possible length. RR joints type are shorter because they have both ends in the rock outcrop. The ratio between the average joint length of $\mathrm{XX}$ and RR types is approximately 2 in investigated granites.

Closed joints are shorter while open and undetermined joints are longer. This difference probably reflects the visibility of joints, since opened joints and/or with soil cover are more distinguishable in rock surface. The same reason could be used to justify the length difference among the joints with and without filling (differences from $8.1 \%$, in the Telões granite, to $66.4 \%$, in the Vale das Gatas granite).

\subsection{Joint spacing}

Spacing values give us a rough idea about the fracture density of rock mass but not take in consideration the number and geometry of joint sets. Post-tectonic granites (Chaves - $\mathrm{CH}$, Pedras Salgadas — PS and Telões - TE) are less fractured and have the greatest joint spacing. The Vale das Gatas (VG), Zedes (ZE), Mourão (MO) and Lousa-Larinho (LL) granites also have high spacing values despite belong to the posttectonic group. The others granites (Águas Santas AS, Campelos - CA and Arejadouro - AR) have low values of joint spacing (Table 5).

Table 6

Relationship between Jv and block size (I.S.R.M., 1978; Toyos et al., 1994)

\begin{tabular}{lll}
\hline $\begin{array}{l}\text { Description } \\
\text { (I.S.R.M., 1978) }\end{array}$ & $\begin{array}{l}\left.\text { Jv (joints } / \mathrm{m}^{3}\right) \\
\text { (I.S.R.M., 1978) }\end{array}$ & $\begin{array}{l}\text { Volume }\left(\mathrm{m}^{3}\right) \\
\text { (Toyos et al., 1994) }\end{array}$ \\
\hline Very large blocks & $<1.0$ & $>25$ \\
Large blocks & $1-3$ & $1-25$ \\
Medium blocks & $3-10$ & $0.025-1$ \\
Small blocks & $10-30$ & $0.001-0.025$ \\
Very small blocks & $>30$ & $<0,001$ \\
\hline
\end{tabular}

Table 7

Block size as a function of Jv value (García, 1996)

\begin{tabular}{lll}
\hline $\mathrm{JV}$ & Indication of block size & Observations \\
\hline$<1.7$ & Large & Commercial \\
1.7 & Optimum & block \\
2.2 & Acceptable & No commercial \\
$>2.2$ & Not acceptable & block \\
\hline
\end{tabular}

There is a difference between the average and the median spacing, as the data spacing does not follow a normal distribution law, as can be seen in Fig. 4. Similar distributions were obtained at the sites studied.

Two statistical tests, the $\mathrm{K}-\mathrm{S}$ (Kolmogorov-Smirnov) and the $\chi^{2}$ (chi-square), were used for seeking the fit to the normal, log-normal, exponential and gamma distributions using specific software (Statsoft, 1993). Mathematical expressions of these distributions and the procedure for conducting these statistical tests can be found in statistical publications (Davis, 1986).

Joint spacing distributions best-fit to log-normal and exponential distributions, with different probabilities, and these results confirm that distributions rarely fit into the normal type as stated by several authors (Priest, 1993; Hudson and Harrison, 1997). Bibliographic research confirms the prevalence of exponential and lognormal distributions (Priest and Hudson, 1976; Hudson and Priest, 1979; Priest and Hudson, 1981; Sen and Kazi, 1984; Grossmann, 1988; Ericsson and Ronge, 1988; Kulatilake, 1988; Priest, 1993; Froldi and Tebaldi, 1995; Hadjigeorgiou et al., 1995; Abu-Zei and Vuillermin, 1997; Hudson and Harrison, 1997). Gamma and Weibbul distributions are less numerous (Rouleau and Gale, 1985; Bardsley et al., 1990; Kulatilake et al., 1993), and normal distributions are unusual. Fractaltype distributions were recently identified (Boadu and Long, 1994; Gumiel and Baltuille, 1998).

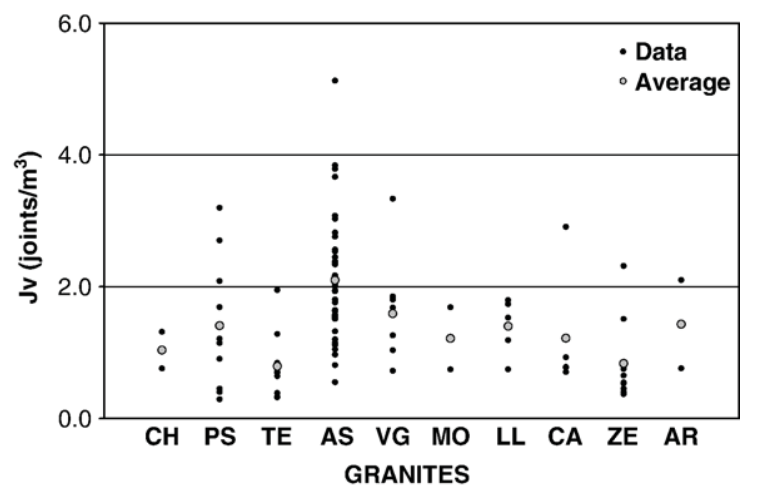

Fig. 5. Distribution of volumetric joint count in studied granites (abbreviations can be found in Fig. 3). 


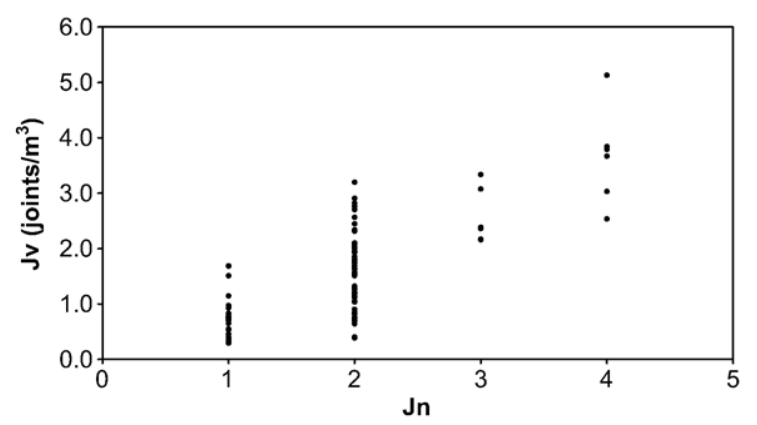

Fig. 6. Relationship between volumetric joint count (Jv) and number of joint sets (Jn).

\subsection{Fracture indices and joint characteristics}

Several indices were proposed for evaluating rockmass fracturing (I.S.R.M., 1978; Castaing and Rabu, 1981; Priest, 1993; Pettifer and Fookes, 1994; Toyos et al., 1994; Sadagah and Sen, 1996; Palmström, 2001; Nefeslioglu et al., 2006), and we applied the volumetric joint count, Jv (I.S.R.M., 1978; Palmström, 1982). Jv is used for evaluation of rock-mass potential to supply ornamental blocks of appropriate size (Tables 6 and 7).

Despite the different numbers of evaluated sites, the Águas Santas granite has the larger Jv variation and the most adverse conditions, whereas the Telões and Zedes granites have lower Jv values (Fig. 5). Post-tectonic granites (Chaves, Pedras Salgadas and Telões) do not have similar Jv values, because the Pedras Salgadas granite contains some places with high JV values. All granites contain places having adverse conditions to commercial exploitation (see Table 7).

Fig. 6 shows the relationship between the volumetric joint count $(\mathrm{Jv})$ and the number of joint sets used for their calculation; obviously, Jv increases together with the number of joint sets. Areas with more than two joint sets are not suitable for quarry development because the

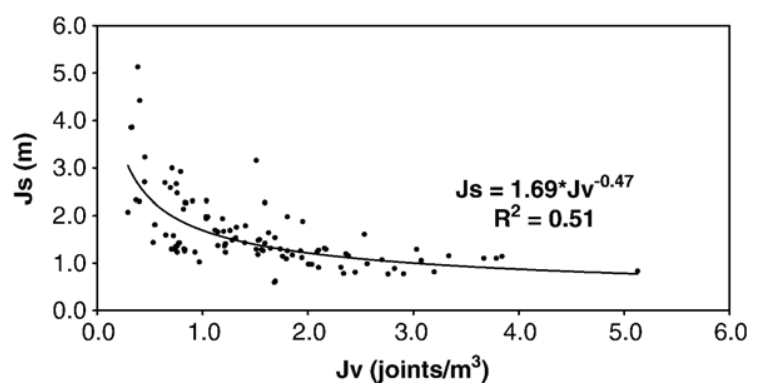

Fig. 7. Relationship between average joint spacing (Js) and volumetric joint count $(\mathrm{Jv})$.

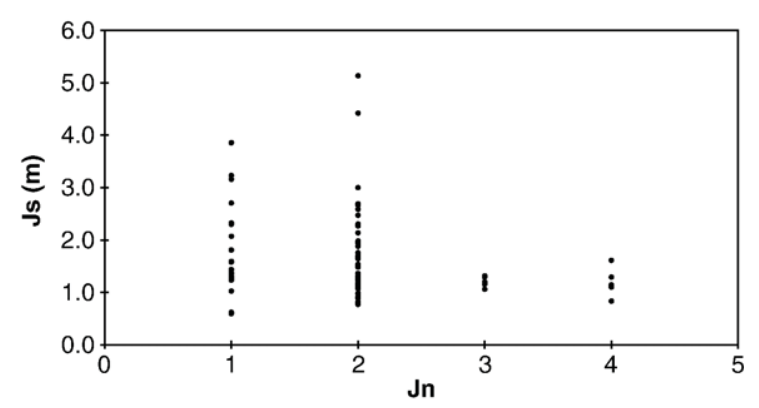

Fig. 8. Relationship between average joint spacing (Js) and number of sets (Jn) used for Jv calculation.

Jv value is $>2.0$, the threshold for obtaining commercial blocks (García, 1996).

Spacing data for each area can provide a view of rock-mass fracturing, and $\mathrm{Jv}$ value is compatible with commercial blocks where the average joint space is $>2.0 \mathrm{~m}$ (Fig. 7). However, a global spacing value $<2.0 \mathrm{~m}$ does not turn impossible the exploitation.

An inverse relationship between the average joint spacing and the number of sets results with an increase of fracture density and a decrease in average spacing (Fig. 8). Joint length is also linked with joint spacing, and for a length $<5 \mathrm{~m}$ the average joint spacing is $<2 \mathrm{~m}$, the limit for commercial block exploitation (Fig. 9).

Taking into consideration the $\mathrm{Jv}$ threshold proposed by García (1996), it is possible to state conditions for exploitation of commercial blocks. These conditions are as follows: If $\mathrm{Jv}<2.0$, the number of joint sets should be $<3$, and the average length preferably $>5 \mathrm{~m}$. If the average joint spacing (all spacing data) is $>2.0 \mathrm{~m}$, the $\mathrm{JV}$ value is suitable for exploitation, although a lower value does not necessarily imply that the site should be rejected. These results are only indicative, as the number of studied places varies from granite to granite.

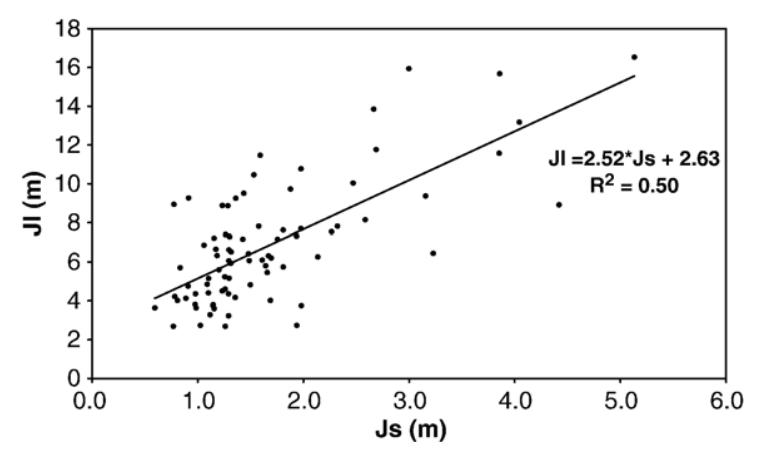

Fig. 9. Relationship between average joint spacing (Js) and average joint length (Jl). 
No relationship was recognized between the persistence index and the other discontinuity characteristics (Fig. 10). However, as the Jv increase, the maximum values of the persistence index decrease. With an increase in the fracture density (Jv increase), the joints are more persistent, and therefore fewer terminate in rock mass.

To overcome dealing with several data we propose a Granite Fracturing Index (GFI), based upon average granite values of volumetric joint count, average number of joint sets and average joint spacing, as follows:

$$
\begin{aligned}
G F I= & 0.5 \times\left(1-\frac{J v}{\overline{J v}}\right)+0.2 \times\left(1-\frac{J n}{\overline{J n}}\right)+0.3 \\
& \times\left(\frac{J_{S}}{\overline{J_{S}}}-1\right)
\end{aligned}
$$

The weights proposed for factors of Eq. (5) take in consideration the importance of the factors in rock exploration. Considering the average values found in studied granites, $\overline{J v}=1.5$ joints $/ \mathrm{m}^{3}, \overline{J n}=1.9$ joints and $\overline{J_{S}}=1.7 \mathrm{~m}$, the GFI expression will be:

$$
\begin{aligned}
G F I= & 0.5 \times\left(1-\frac{J v}{1.5}\right)+0.2 \times\left(1-\frac{J n}{2}\right) \\
& +0.3 \times\left(\frac{J_{s}}{1.7}-1\right)
\end{aligned}
$$

Two perpendicular joint sets would be the normal situation on granitic rocks, and Jn always takes a natural value; therefore, we use $\mathrm{Jn} / 2$ in the second term of the GFI expression. GFI tends toward zero when joint characteristics fall to average values, negative values being worse and positive values better. A scattering of results allows comparing more properly the several sites of a particular granite, improving the probability of making a better choice for establishing a quarry. Nevertheless, some redundancy is inherent by using correlated parameters in GFI determinations.

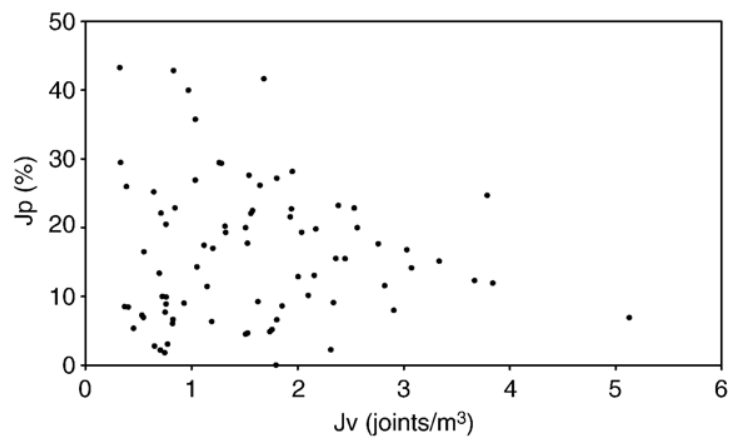

Fig. 10. Relationship between persistency index (Jp) and volumetric joint count $(\mathrm{Jv})$.

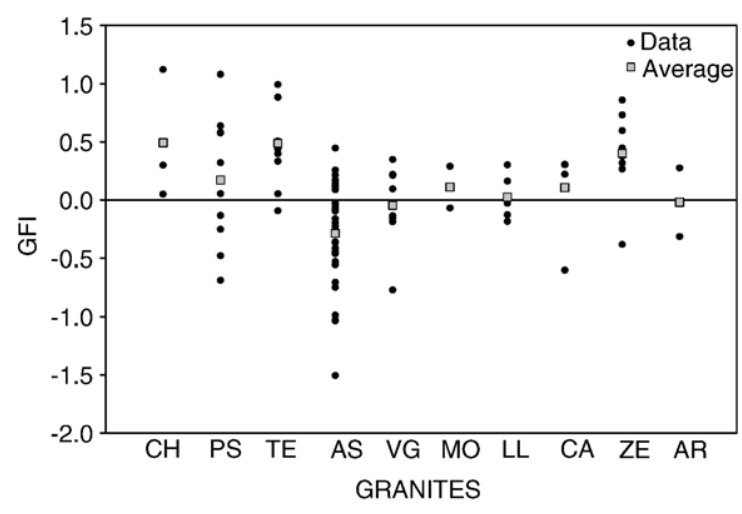

Fig. 11. Distribution of GFI values in granites studied (abbreviations can be found in Fig. 3).

Fig. 11 shows the average data obtained by Eq. (6). Post-tectonic granites (Chaves - CH, Telões - TE and Pedras Salgadas) always have a GFI $>0$; the Pedras Salgadas granite has lower GFI values that possibly are related to a high quarry fracture density, as revealed by field work. The Águas Santas (AS) granite has a wide GFI distribution, which is consistent with fracture patterns observed in new quarries near the sites studied.

GFI is reliable for determining local areas that are suitable for dimension granite exploitation. However, GFI data can be considered a complete fracture concept only when the influence of each factor is understood. Graphical representation of the signal factors used for GFI computation makes it easier to compare places with similar GFI values (Fig. 12). Fig. 13 corresponds to an area in the Águas Santas (AS) granite where six places were studied. From this study it is possible to compare, for example, the GFI values in places 3 and 5 (Fig. 13). Those places have similar GFI's, but place 3 has Jv and Js values smaller than average.

The application of this methodology for other granites and/or rocks should be made only after gaining a knowledge of fracture characteristics. Eq. (6) might need some modifications to represent the average characteristics of overall discontinuities.

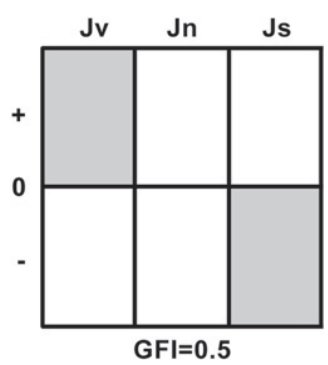

Fig. 12. Graphical representation of the GFI factors. 


\section{Conclusions}

In the granites studied, the joint patterns and the regional faulting are related to each other. $\mathrm{N} 10^{\circ}-40^{\circ} \mathrm{E}$ is the strike of the principal joint set identified in studied places, and this observation is in accordance with the tectonic fracture pattern of NE Portugal. The primary fracturing sets $\left(\mathrm{N} 40^{\circ}-60^{\circ} \mathrm{W}\right.$ and $\left.\mathrm{N} 30^{\circ}-50^{\circ} \mathrm{E}\right)$ are observed in some places.

XX joint type is the more common and the RR type the less frequent. The persistency index (Jp) varies from 3.3\% (Lousa-Larinho granite) to $25.4 \%$ (Telões granite).

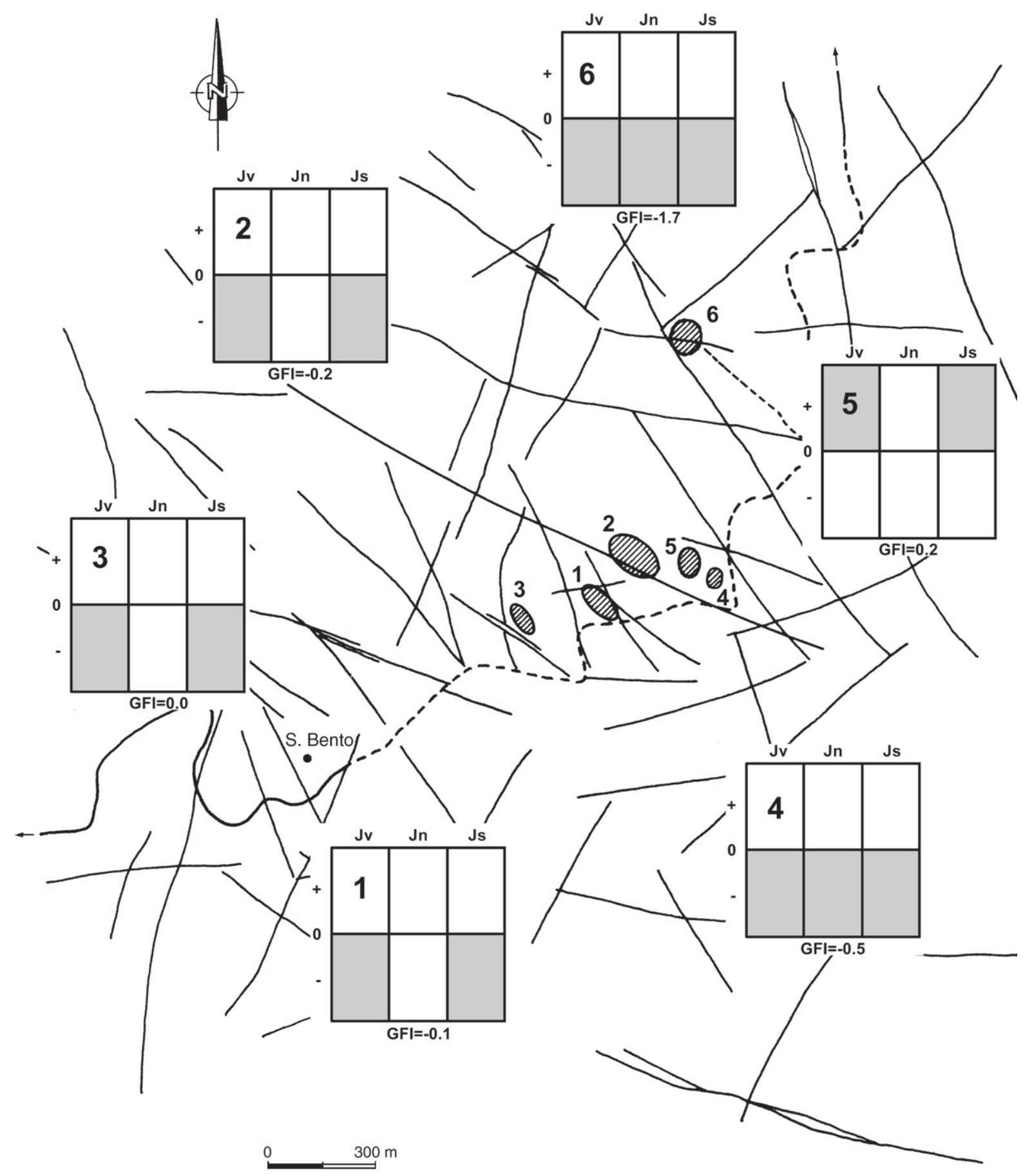

Fig. 13. Graphical representation of GFI factors in the Águas Santas granite (S. Bento area). 
The joints of the post-tectonic granites are more lengthy than those of the syntectonic granites. The outcrops of post-tectonic granites are large and make possible the joint surveying in high areas while weathering, fracturing and soil cover avoid the observation in syntectonic granites.

The joint spacing data best fits the log-normal and exponential distributions. Post-tectonic granites have a low joint density and therefore higher values of joint spacing.

Volumetric joint count (Jv) improves the evaluation of the suitability to quarry development, but this method must be employed cautiously because is influenced by other variables. Joints with both ends in rock mass have a small influence on rock fracturing at depth, so the value of JV will be high and not realistic. The number of joint sets also influences the $\mathrm{Jv}$ calculation, and are required less than three to profitable exploitation. Joint length preferably should be $>5 \mathrm{~m}$, and all places with joint spacing $>2.0 \mathrm{~m}$ can be exploitable. These relationships provide useful information for exploration studies in these granites, but their extrapolation to other regions, rocks and tectonic settings must be avoid before acquire detailed information.

Granite Fracturing Index (GFI) was defined by integrating the most important joint characteristics in granite, such as average values of volumetric joint count, average number of joint sets and average joint spacing. The GFI is used as a tool for choosing the best sites for granite exploitation. The results provide a global vision of the fracture characteristics and their interrelationship enabling the best choice for quarry installation. The categorization of the studied sites is more important than any characteristic/index since turns possible to choose the best site from a group.

A final recommendation is necessary regarding the data-acquisition process. The method identifies all fractures in rock outcrops but requires an enormous amount of field work, and some experience is necessary for successful joint observation. Special care is required in the acquisition process of discontinuity characteristics to avoid some difficulties related to visibility of the joints, especially the closed ones and/or where the rock surface is covered by lichen.

\section{Acknowledgements}

The author is grateful to the Centro de GeociênciasUniversidade de Coimbra for providing partial financial support for this study. The author would like to thank Dr. Candan Gokceoglu and the other anonymous reviewer for their constructive comments.

\section{References}

Abu-Zei, N., Vuillermin, F., 1997. Geomechanical characterization of the outcropping rock masses in the immediate vicinity of Wadi El-Kaffrein dam site (Jordan). Bulletin of International Association of Engineering Geology 44, 3-17.

Balk, R., 1937. Structural behaviour of igneous rocks. Geological Society of America, Memoir 5, 117.

Bardsley, W.E., Major, T.J., Selby, M.J., 1990. Note on a Weibull property for joint spacing analysis. International Journal of Rock Mechanics and Mining Sciences \& Geomechanics Abstracts 11 (2), 133-134

Boadu, F.K., Long, L.T., 1994. The fractal character of fracture spacing and RQD. International Journal of Rock Mechanics and Mining Sciences \& Geomechanics Abstracts 31 (2), 127-134.

Castaing, C., Rabu, D., 1981. Apports de la géologie à la recherche et l'exploitation de pierres de taille (roches ornementales et de construction). Bulletin de Bureaux de Recherches Géologiques et Minières (2), Section III, 11, 81-97.

Cruden, D.M., 1977. Describing the size of discontinuities. International Journal of Rock Mechanics and Mining Sciences \& Geomechanics Abstracts 14, 133-137.

Davis, J.C., 1986. Statistics and Data Analysis in Geology. Jonh Wiley \& Sons, Inc., New York. 646 pp.

Dutartre, P., 1982. Ètude de la fracturation du granite de la Margeride (région de Saint-Alban-Sur-Limagnole-Lozère). Geometrie, Cinématique, Densité des Fractures. Documents du BRGM, vol. n. 41, p. 344.

Ericsson, L., Ronge, S.H., 1988. Fracture mapping on outcrops in crystalline bedrock: a case study within the subCambrian peneplain, southern Sweden. Proc. 29th US Symposium on Rock Mechanics, pp. 731-732.

Froldi, P., Tebaldi, E., 1995. Joint spacing pattern prediction in flyschoid rock mass: examples from Northern Apennines, Italy. Proc. 8th International Congress on Rock Mechanics, pp. $13-18$.

Gamond, J.F., Giraud, A., 1982. Identification des zones de faille à l'aide des associations de fractures de second ordre. Bulletin de la Société Géologique de France 24 (4), 755-762.

García, E.O., 1996. Investigación de yacimientos. In: Jimeno, C.L. (Ed.), Manual de rocas Ornamentales. Entorno Grafico, Madrid, pp. 139-174.

Greco, R., Sorriso-Valvo, M., 2005. Relationships between joint apparent separation, Schmidt hammer rebound value, and distance to faults, in rocky outcrops, Calabria, Southern Italy. Engineering Geology 78, 309-320.

Grossmann, N.F., 1988. About the set joint intensity. In: Romana, N. (Ed.), Rock Mechanics and Power Plants. Balkema, Rotterdam, pp. 41-47.

Gumiel, P., Baltuille, J.M., 1998. Análisis geométrico de sistemas de fracturación en canteras de rocas ornamentales. Ensayo de aplicación de modelización fractal a un macizo granítico. Proc. II Congreso International de la Piedra, p. 12. CD.

Hadjigeorgiou, J., Lessard, J.F., Villaescusa, E., Germain, P., 1995. An appraisal of structural mapping techniques. In: Rossmanith, H.-P. (Ed.), Mechanics of Jointed and Faulted Rock. Balkema, Rotterdam, pp. 193-199.

Hudson, J.A., Harrison, J.P., 1997. Engineering Rock Mechanics: an Introduction to the Principles. Elsevier, Oxford. 444 pp.

Hudson, J.A., Priest, J.P., 1979. Discontinuities and rock mass geometry. International Journal of Rock Mechanics and Mining Sciences \& Geomechanics Abstracts 16, 339-362. 
I.S.R.M., 1978. Suggested methods for the quantitative description in rock masses. International Journal of Rock Mechanics and Mining Sciences \& Geomechanics Abstracts 15 (6), 319-368.

Jiang, Y., Li, B., Yosihiko Tanabashi, Y., 2006. Estimating the relation between surface roughness and mechanical properties of rock joints. International Journal of Rock Mechanics and Mining Science 43, 837-846.

Jimenez-Rodriguez, R., Sitar, N., 2006a. A spectral method for clustering of rock discontinuity sets. International Journal of Rock Mechanics and Mining Science 43, 1052-1061.

Jimenez-Rodriguez, R., Sitar, N., 2006b. Inference of discontinuity trace length distributions using statistical graphical models. International Journal of Rock Mechanics \& Mining Science 43, 877-893.

Kulatilake, P.H.S.W., 1988. State-of-art in stochastic joint geometry modeling. Proc. 29th US Symposium on Rock Mechanics, pp. 213-229.

Kulatilake, P.H.S., Wathugala, D.N., Stephansson, O., 1993. Joint network modeling with a validation exercise in Stripa mine. International Journal of Rock Mechanics and Mining Sciences \& Geomechanics Abstracts 30 (5), 503-526.

Lisboa, J.V.V., 1998. Preliminary study on fracturing in the Santa Eulália plutonic complex (Alentejo, Portugal). Proc. II Congresso Internacional de la Piedra, Madrid, p. 10. CD.

Lourenço, J., Mateus, A., Coke, C., Ribeiro, A., 2002. A zona de falha Penacova-Régua-Verín na região de Telões (Vila Pouca de aguiar), alguns elementos determinantes da sua evolução em tempos tardivariscos. Comum. Inst. Geol. e Mineiro, vol. 89, pp. 105-122.

Maerz, N.H., Germain, P., 1996. Block size determination around underground openings using simulations. Proceedings of the FRAGBLAST 5 Workshop on Measurement of Blast Fragmentation, Montreal, Canada, pp. 215-223.

Marre, J., 1986. The Structural Analysis of Granitic Rocks. North Oxford Academic Publishers. 123 pp.

Matos, A.V., 1991. A geologia da região de Vila Real: evolução do Complexo Xisto-Grauváquico, do Ordovícico, dos granitóides hercínicos e dos depósitos minerais associados. Tese de Doutoramento. Universidade de Trás-os-Montes e Alto Douro. 312 pp.

Morais, A.I.F., 2003. Inventariação, Caracterização e Valorização das Pedreiras do Granito Amarelo Real. Tese de Mestrado. Departamento de Geologia, Universidade de Trás-os-Montes e Alto Douro. 218 pp.

Nefeslioglu, H.A., Gokceoglu, C., Sonmez, H., 2006. Indirect determination of weighted joint density (wJd) by empirical and fuzzy models: Supren (Eskisehir, Turkey) marbles. Engineering Geology 85, 251-269.

Pahl, P.J., 1981. Estimating the mean length of discontinuity traces. International Journal of Rock Mechanics and Mining Sciences \& Geomechanics Abstracts 18, 221-228.

Palmström, A., 1982. The volumetric joint count - a useful and simple measure of the degree of rock jointing. Proc. 4th Int. Cong. Int. Assoc. Eng. Geol., vol. 5. A.A. Balkema, pp. 221-228.

Palmström, A., 2001. Measurement and characterization of rock mass jointing. In: Sharma, V.M., Saxena, K.R. (Eds.), In-situ Characterization of Rocks. Balkema Publishers, pp. 49-97.

Pettifer, G.S., Fookes, P.G., 1994. A revision of the graphical method for assessing the excavatability of rock. Quarterly Journal of Engineering Geology 27, 145-164.

Pitcher, W.S., 1993. The Nature and Origin of Granite. Chapman \& Hall, London. 321 pp.
Priest, S.D., 1993. Discontinuity Analysis for Rock Engineering Chapman \& Hall, London. 473 pp.

Priest, S.D., Hudson, J.A., 1976. Discontinuity spacing in rock. International Journal of Rock Mechanics and Mining Sciences \& Geomechanics Abstracts 13, 135-148.

Priest, S.D., Hudson, J.A., 1981. Estimation of discontinuity spacing and trace length using scanline. International Journal of Rock Mechanics and Mining Sciences \& Geomechanics Abstracts 18, 183-197.

Pine, R.J., Coggan, J.S., Flynn, Z.N., Elmo, D., 2006. The Development of a new numerical modelling approach for naturally fractured rock masses. Rock Mechanics and Rock Engineering 39 (5), 395-419.

Robertson, A.M., 1970. The interpretation of geological factors for use in slope theory. Symp. on Planning Open Pit Mines. Balkema, Amsterdam, pp. 55-71.

Rouleau, A., Gale, J.E., 1985. Statistical characterization of the fracture system in the stripa granite, Sweden. International Journal of Rock Mechanics and Mining Sciences \& Geomechanics Abstracts 22 (6), 353-367.

Sadagah, B.H., Sen, Z., 1996. Naturally fractured rock mass quality zonation in Saudi Arabia. Quarterly Journal of Engineering Geology \& Hydrogeology 29, 205-208.

Sen, Z., Kazi, A., 1984. Discontinuity spacing and RQD estimates from finite length scanlines. International Journal of Rock Mechanics and Mining Sciences \& Geomechanics Abstracts 21 (4), 203-212.

Song, J.-J., 2006. Estimation of a joint diameter distribution by an implicit scheme and interpolation technique. International Journal of Rock Mechanics \& Mining Science 43, 512-519.

Sonmez, H., Nefeslioglu, H.A., Gokceoglu, C., 2004. Determination of wJd on rock exposures including wide spaced joints. Rock Mechanics and Rock Engineering 37 (5), 403-413.

Sousa, L.M.O., 2000. Estudo da fracturação e das características físico-mecânicas de granitos da região de Trás-os-Montes com vista à sua utilização como rocha ornamental. Tese de Doutoramento. Universidade de Trás-os-Montes e Alto Douro. 358 pp.

Sousa, L.M.O., Suárez del Río, L.M., Calleja, L., Ruiz de Argandoña, V., Rey, A.R., 2005. Influence of microfractures and porosity on the physico-mechanics properties and weathering of ornamental granites. Engineering Geology 77, 153-168.

Statsoft, 1993. Statistica for Windows. Release 4.5.

Tansi, C., Sorriso-Valvo, M., Greco, R., 2000. Relationships between joint separation and faulting: an initial numerical appraisal Engineering Geology 52, 225-230.

Tomašic, I., 1994. The influence of discontinuity fabric and other factors on optimum exploitation of dimension stone. Rudarskogeološko-naftni zbornik 6, 101-105.

Toyos, J.M., Taboada, J., Lombardero, M., Romero, J.A., Menendez, A., 1994. Estudio de las descontinuidades en yacimientos de roca ornamental. Boletim de Geologico y Minero 105 (1), 110-118.

Wang, L.G., Yamashita, S., Sugimoto, F., Pan, C., Tan, G., 2003. A methodology for predicting the in situ size and shape distribution of rock blocks. Rock Mechanics and Rock Engineering 36 (2), $121-142$

Xing, Z., Guohua, L., 1990. Estimation of confidence bounds for mean trace length of discontinuities using scanline surveys. International Journal of Rock Mechanics and Mining Sciences \& Geomechanics Abstracts 27 (3), 207-212. 